\title{
OCENA KONDYCJI EKONOMICZNO-FINANSOWEJ PRZEDSIĘBIORSTWA PRODUKUJĄCEGO I SPRZEDAJĄCEGO ROŚLINY OZDOBNE
}

\author{
Dawid Olewnicki, Kinga Cichocka \\ Wydział Ogrodnictwa, Biotechnologii i Architektury Krajobrazu, \\ Szkoły Głównej Gospodarstwa Wiejskiego w Warszawie \\ Dziekan Wydziału: prof. dr hab. Wojciech Wakuliński
}

\begin{abstract}
Słowa kluczowe: rośliny ozdobne, produkcja szklarniowa, analiza ekonomiczno-finansowa Key words: ornamental plants, greenhouse production, economic and financial analysis

JELcode: M21, O12, Q12

S y n o p s i s. Celem opracowania była ocena kondycji ekonomiczno-finansowej wybranego przedsiębiorstwa produkującego i sprzedającego rośliny ozdobne w latach 2010-2016. Dokonano oceny struktury aktywów i pasywów oraz wskaźników zadłużenia, rentowności (ROA i ROE) oraz płynności bieżącej (CR - I stopnia) i szybkiej (QR - II stopnia). Wielkości wskaźników obliczonych na podstawie danych zawartych w sprawozdaniach finansowych nie wykazały istotnie niepokojących zjawisk. W latach 2014-2016 spółka osiągała satysfakcjonujący poziom wskaźnika ROA, tj. wyższy niż poziom inflacji, oraz wskaźnika ROE, którego wartość nie spadła poniżej 9,56\%.
\end{abstract}

\section{WSTĘP}

W Polsce od lat 90. XX wieku zwiększa się popyt indywidualny i instytucjonalny na rośliny ozdobne, a bezpośrednią przyczyną tego zjawiska jest wzrost zamożności społeczeństwa. Rosnący popyt wpłynął na rozwój tej produkcji, która należy do najintensywniej prowadzonych gałęzi produkcji roślinnej [Jabłońska 2007, Olewnicki 2011]. Pomimo tak dużego znaczenia tej gałęzi produkcji, wiedza o krajowym rynku kwiaciarskim jest nadal ograniczona i oparta głównie na szacunkach, a dostępne dane oficjalne są bardzo ogólne [Wróblewska 2007, Olewnicki 2015]. Jak wskazał Dawid Olewnicki [Olewnicki 2017], statystyka GUS nie uwzględnia ogromnego zróżnicowania produkcji roślin ozdobnych, a wiedza o potencjale produkcyjnym przedsiębiorstw, również ich wynikach finansowych, może mieć wpływ na dalszy rozwój tej gałęzi produkcji.

Według danych GUS ze spisu rolnego 2002, produkcją roślin ozdobnych zajmowało się w Polsce 37,76 tys. gospodarstw na łącznej powierzchni około 8,9 tys. ha [Domagalska-Grędys 2009]. W roku 2011 areał ten wzrósł do 12,15 tys. ha [Marosz 2017]. Obecnie trudno precyzyjnie określić całkowitą liczbę gospodarstw zajmujących się tą produkcją oraz powierzchnię ich upraw. Więcej informacji dostarczają powszechne spisy rolne, jed- 
nak najbliższy planowany jest dopiero na 2020 rok, a poprzedni był w 2010 roku. Poza potrzebą gromadzenia informacji statystycznych, istotnym zagadnieniem do rozważań powinna być także ocena kondycji ekonomiczno-finansowej przedsiębiorstw zajmujących się produkcją kwiaciarską, która w literaturze jest również niezwykle rzadko poruszana. Podstawową przesłanką do takich analiz może być fakt, że w wyniku wzrostu chłonności krajowego rynku od kilkunastu lat Polska jest rosnącym importerem netto kwiatów ciętych. Rosnący import roślin ozdobnych stanowi zatem konkurencję dla produkcji krajowej, w której przypadku koszty pracy oraz technologii są znacząco wyższe od kosztów produkcji w krajach Afryki i Ameryki Łacińskiej [Olewnicki, Jabłońska 2018].

Każde przedsiębiorstwo chcące utrzymać się na rynku lub zwiększyć w nim udział musi sięgnąć zatem po narzędzia analityczne. Pozwala to nie tylko na usprawnienie procesu podejmowania bieżących decyzji, ale również umożliwia trafniejsze podjęcie dalekosiężnych decyzji strategicznych i wskazanie potencjalnych dróg rozwoju [Szczecińska 2014].

Celem opracowania była ocena kondycji ekonomiczno-finansowej wybranego przedsiębiorstwa produkującego i sprzedającego rośliny ozdobne.

\section{METODYKA I MATERIAŁ BADAWCZY}

Analizę ekonomiczno-finansową wykonano na podstawie sprawozdań pobranych $\mathrm{z}$ bazy EMIS, tj. polskiego serwisu zawierającego obszerne informacje ekonomiczne, finansowe i polityczne dotyczące m.in. naszego kraju. Serwis ten umożliwia korzystanie z pełnych sprawozdań finansowych spółek publicznych i niepublicznych oraz różnych analiz i raportów branżowych. Korzystać można także z notowań giełdowych, statystyk i danych makroekonomicznych. Z powyższej bazy wybrano sprawozdania finansowe za lata 2010-2016 dla jednego z przedsiębiorstw zajmujących się produkcją i sprzedażą roślin ozdobnych. Część danych w sprawozdaniach dostępna była od roku 2013, co warunkowało obliczenie wybranych wskaźników dla lat 2013-2016.

Analizowane przedsiębiorstwo jest producentem i dystrybutorem kwiatów w Polsce. Obsługuje ono zarówno klientów detalicznych, jak i hurtowych, a jego oferta obejmuje ponad 300 gatunków i odmian roślin. Na potrzeby analizy oraz oceny sytuacji ekonomiczno-finansowej wykorzystano analizę struktury aktywów i pasywów oraz wskaźniki płynności, zadłużenia oraz rentowności (tabela 1.). Do oceny płynności analizowanego podmiotu wykorzystano wskaźniki płynności bieżącej (CR - I stopnia) oraz szybkiej (QR - II stopnia). Pierwszy ze wskaźników informuje o zdolności przedsiębiorstwa do spłacenia wszystkich zobowiązań finansowych z majątku obrotowego, natomiast drugi wskaźnik o możliwości pokrycia zobowiązań wymagalnych.

Ocena poziomu zadłużenia przedsiębiorstwa pozwoliła ustalić, czy środki przedsiębiorstwa pochodzą od właścicieli, czy też od zewnętrznych kredytodawców. W przypadku niniejszego opracowania wykorzystano wskaźnik ogólnego zadłużenia, który obrazuje najbardziej ogólną strukturę finansowania aktywów przedsiębiorstwa. Obliczono również wskaźniki rentowności, które służą zasadniczo do oceny zdolności generowania zysków z zaangażowanych przez podmioty kapitałów. Do oceny rentowności analizowanej jednostki wykorzystano wskaźnik rentowności aktywów i kapitałów własnych. Ustalono również dynamikę zmian wybranych składników analizy finansowej, przyjmując za $100 \%$ pierwszy rok badanego okresu. 
Tabela 1. Wskaźniki finansowe i ich wzory wykorzystane w badaniach

\begin{tabular}{ll}
\hline Nazwa & Wzór \\
\hline Wskaźnik płynności bieżącej CR & $\frac{\text { Aktywa obrotowe }}{\text { Zobowiązania krótkoterminowe }}$ \\
Wskaźnik płynności szybkiej QR & $\frac{\text { Aktywa obrotowe }- \text { Zapasy }}{\text { Zobowiqzania krótkoterminowe }}$ \\
Wskaźnik ogólnego zadłużenia & $\frac{\text { Kapitał obcy }}{\text { Aktywa ogółem }}$ \\
Wskaźnik zadłużenia kapitału własnego & $\frac{\text { Zobowiąania ogołem }}{\text { Kapitał własny }}$ \\
Wskaźnik zadłużenia długoterminowego & $\frac{\text { Zobowiazania długoterminowe }}{\text { Kapitał własny }}$ \\
Wskaźnik rentowności aktywów ROA & $\frac{\text { Zysk netto }}{\text { Aktywa ogółem }} \times 100$ \\
Wskaźnik rentowności kapitału własnego ROE & $\frac{\text { Zysk netto }}{\text { Kapital własny }} \times 100$ \\
\hline
\end{tabular}

Źródło: opracowanie własne na podstawie [Dynus i in. 2002, Bednarski 2007, Antczak 2014, Gad 2015].

\section{WYNIKI BADAŃ I DYSKUSJA}

Biorąc pod uwagę strukturę majątku oraz źródeł finansowania analizowanego przedsiębiorstwa, można zauważyć wzrost jego aktywów ogółem z poziomu 10361 tys. zł w 2010 r. do 20021 tys. zł w 2016 r. W 2016 roku wartość aktywów trwałych analizowanego podmiotu była prawie dwukrotnie wyższa niż w roku 2010. Zauważalny jest także istotny wzrost aktywów trwałych w badanym okresie z 210 tys. do około 1,5 mln zł, tj. aż o 618\%, a także wzrost aktywów obrotowych z 10151 tys. do 18513 tys. zł, tj. o $82 \%$. Aktywa obrotowe miały największy udział w aktywach ogółem, co jest charakterystyczne dla jednostek zajmujących się sprzedażą. W całym badanym okresie udział tego składnika majątku przekraczał $92 \%$ (tabela 2.).

W 2016 roku zauważalny jest znaczący wzrost aktywów trwałych w analizowanym przedsiębiorstwie, co zostało spowodowane zwiększeniem wartości nieruchomości. Jeśli chodzi o aktywa obrotowe, to ich wartość w 2013 roku (18 931 tys. zł) miała wyższy poziom niż w roku 2016 (tabela 3.). Spowodowane to mogło być znaczącym wzrostem należności krótkoterminowych w wyniku wzrostu sprzedaży. Należy jednak pamiętać, iż nadmierny wzrost należności handlowych może być niekorzystny, gdyż środki finansowe są zamrożone. Zamiast tego powinny obsługiwać działalność przedsiębiorstwa [Pomykalska, Wypych 2000]. W 2015 roku wzrósł zaś udział aktywów obrotowych, co wynikało ze zwiększenia poziomu zapasów. Wzrost taki jest uzasadniony w przypadku rozwoju działalności lub zmiany asortymentu. W przeciwnym wypadku ich nadmierny wzrost jest objawem negatywnym i może świadczyć o problemach przedsiębiorstwa z zarządzaniem 
Tabela 2. Wartość i struktura majątku badanego przedsiębiorstwa w latach 2010-2016

\begin{tabular}{ccccccccc}
\hline Lata & $\begin{array}{c}\text { Aktywa } \\
\text { trwałe } \\
\text { [tys. zł }]\end{array}$ & $2010=100$ & $\begin{array}{c}\text { Udział } \\
{[\%]}\end{array}$ & $\begin{array}{c}\text { Aktywa } \\
\text { obrotowe } \\
\text { [tys. zł] }\end{array}$ & $2010=100$ & $\begin{array}{c}\text { Udział } \\
{[\%]}\end{array}$ & $\begin{array}{c}\text { Aktywa } \\
\text { ogółem } \\
\text { [tys. zł }]\end{array}$ & $2010=100$ \\
\hline 2010 & 210 & 100 & 2 & 10151 & 100 & 98 & 10361 & 100 \\
2011 & 548 & 261 & 5 & 11393 & 112 & 95 & 11941 & 115 \\
2012 & 382 & 182 & 3 & 13398 & 132 & 97 & 13780 & 133 \\
2013 & 490 & 233 & 3 & 18931 & 186 & 97 & 19421 & 187 \\
2014 & 897 & 427 & 6 & 15384 & 152 & 94 & 16281 & 157 \\
2015 & 872 & 415 & 4 & 18955 & 187 & 96 & 19827 & 191 \\
2016 & 1508 & 718 & 8 & 18513 & 182 & 92 & 20021 & 193 \\
\hline
\end{tabular}

Źródło: opracowanie własne na podstawie danych z bazy EMIS, https://www.emis.com/php/macro/overview/index (dostęp 22.11.2017 r.).

Tabela 3. Wartość i struktura aktywów analizowanego przedsiębiorstwa w latach 2013-2016

\begin{tabular}{|c|c|c|c|c|c|c|c|c|}
\hline \multirow{3}{*}{ Wyszczególnienie } & \multicolumn{8}{|c|}{ Wielkości w roku } \\
\hline & \multicolumn{2}{|c|}{2013} & \multicolumn{2}{|c|}{2014} & \multicolumn{2}{|c|}{2015} & \multicolumn{2}{|c|}{2016} \\
\hline & [tys. zł] & $\begin{array}{c}\text { udział } \\
{[\%]}\end{array}$ & [tys. zł] & $\begin{array}{c}\text { udział } \\
{[\%]}\end{array}$ & [tys. zł] & $\begin{array}{c}\text { udział } \\
{[\%]}\end{array}$ & [tys. zł] & $\begin{array}{c}\text { udział } \\
{[\%]}\end{array}$ \\
\hline Aktywa ogółem & 19421 & 100 & 16281 & 100 & 19827 & 100 & 20021 & 100 \\
\hline Aktywa trwałe, w tym & 490 & 3 & 897 & 6 & 872 & 4 & 1508 & 8 \\
\hline Rzeczowe aktywa trwałe & 476 & 2 & 886 & 5 & 488 & 2 & 1484 & 7 \\
\hline Nieruchomości & 133 & 1 & 102 & 1 & 78 & - & 1141 & 6 \\
\hline Pojazdy i urządzenia & 335 & 2 & 779 & 5 & 399 & 2 & 330 & 2 \\
\hline Pozostałe składniki majątku & 8 & - & 5 & - & 10 & - & 13 & - \\
\hline Środki trwałe w budowie & 10 & - & 10 & - & 384 & 2 & 14 & - \\
\hline $\begin{array}{l}\text { Wartości niematerialne i prawne } \\
\text { oraz wartość firmy }\end{array}$ & 5 & - & 1 & - & - & - & 10 & - \\
\hline $\begin{array}{l}\text { Pozostałe wartości } \\
\text { niematerialne i prawne }\end{array}$ & 5 & - & 1 & - & - & - & 10 & - \\
\hline Aktywa obrotowe, w tym & 18931 & 97 & 15384 & 94 & 18955 & 96 & 18513 & 92 \\
\hline Zapasy & 1792 & 9 & 1328 & 8 & 2890 & 15 & 1734 & 9 \\
\hline Pozostałe zapasy & 1792 & 9 & 1328 & 8 & 2890 & 15 & 1734 & 9 \\
\hline Należności handlowe i inne & 15923 & 82 & 11191 & 69 & 14372 & 72 & 16129 & 81 \\
\hline Należności handlowe & 15339 & 79 & 10844 & 67 & 13982 & 71 & 15828 & 79 \\
\hline $\begin{array}{l}\text { Pozostałe należności } \\
\text { krótkoterminowe }\end{array}$ & 11 & - & 8 & - & 8 & - & 12 & - \\
\hline Należności z budżetu państwa & 5734 & 3 & 338 & 2 & 381 & 2 & 289 & 1 \\
\hline $\begin{array}{l}\text { Zaliczki, rozliczenia } \\
\text { międzyokresowe i pozostałe } \\
\text { aktywa }\end{array}$ & 584 & 3 & 603 & 4 & 558 & 3 & 574 & 3 \\
\hline Gotówka i ekwiwalenty & 632 & 3 & 2262 & 14 & 1135 & 6 & 76 & 0 \\
\hline $\begin{array}{l}\text { Środki pieniężne w kasie i na } \\
\text { rachunkach }\end{array}$ & 632 & 3 & 2262 & 14 & 1135 & 6 & 76 & 0 \\
\hline
\end{tabular}

Źródło: opracowanie własne na podstawie danych z bazy EMIS, https://www.emis.com/php/macro/overview/ index (dostęp 22.11.2017 r.). 
wolumenem produkcji lub o problemach ze sprzedażą asortymentu. Taka sytuacja może prowadzić do trudności finansowych jednostki.

W analizowanym przedsiębiorstwie zauważalny był wzrost poziomu kapitału własnego z 2118 tys. zł w 2010 r. do 3808 tys. zł w 2016 r. Wzrost ten był uwarunkowany zwiększeniem się następujących pozycji bilansowych: wynik finansowy wzrósł z 117 tys. do 364 tys. zł oraz pozostałe składowe kapitału własnego z poziomu 1801 tys. do 3243 tys. zł. Jednocześnie zaobserwowano wzrost zobowiązań z 8243 tys. zł do 16213 tys. zł. Wzrost ten wynikał m.in. z pojawienia się w bilansie spółki zobowiązania długoterminowego w 2016 roku. W analizowanym okresie udział zobowiązań w pasywach ogółem wynosił od $80 \%$ do $87 \%$ (tabela 4.), natomiast udział kapitałów własnych w pasywach ogółem stanowił od $13 \%$ do $20 \%$.

Tabela 4. Wartość i struktura kapitału analizowanego przedsiębiorstwa w latach 2010-2016

\begin{tabular}{cccccccc}
\hline Lata & $\begin{array}{c}\text { Kapitały } \\
\text { własne } \\
\text { [tys. zł] }\end{array}$ & $2010=100$ & $\begin{array}{c}\text { Udział } \\
{[\%]}\end{array}$ & $\begin{array}{c}\text { Zobowiązania } \\
{[\text { tys. zł }]}\end{array}$ & $2010=100$ & $\begin{array}{c}\text { Udział } \\
{[\%]}\end{array}$ & $\begin{array}{c}\text { Pasywa } \\
\text { ogółem } \\
{[\text { tys. zł] }}\end{array}$ \\
\hline 2010 & 2118 & 100 & 20 & 8243 & 100 & 80 & 10361 \\
2011 & 2217 & 105 & 19 & 9725 & 118 & 81 & 11942 \\
2012 & 2386 & 113 & 17 & 11394 & 138 & 83 & 13780 \\
2013 & 2506 & 118 & 13 & 16915 & 205 & 87 & 19421 \\
2014 & 2984 & 141 & 18 & 13297 & 161 & 82 & 16281 \\
2015 & 3443 & 163 & 17 & 16384 & 199 & 83 & 19827 \\
2016 & 3808 & 180 & 19 & 16213 & 197 & 81 & 20021 \\
\hline Źródło: opracowanie własne na podstawie danych z bazy EMIS, https://www.emis.com/php/macro/overview/ \\
\multicolumn{7}{r}{ index (dostęp 22.11.2017 r.). }
\end{tabular}

Najwyższy poziom zobowiązań obserwowany był w 2013 roku, kiedy wystąpił zarówno wzrost pożyczek krótkoterminowych, jak i zobowiązań handlowych. W 2016 roku zaobserwowano spadek udziału zobowiązań, w szczególności zobowiązań krótkoterminowych, co wiązało się ze spłatą pożyczki krótkoterminowej z 2015 roku. Również w 2016 roku spółka zaciągnęła zobowiązanie długoterminowe w wysokości 4520 tys. zł. Pozostałe zobowiązania krótkoterminowe oraz krótkoterminowe rozliczenia międzyokresowe stanowiły udział poniżej $1 \% \mathrm{w}$ pasywach ogółem. Udział zobowiązań $z$ tytułu podatku dochodowego nie przekraczał w badanym okresie $2 \%$.

Na podstawie przeprowadzonych badań można stwierdzić, iż badane przedsiębiorstwo nie ma poważnych problemów z regularną spłatą zobowiązań (tabele 5. i 6.). Pozytywnym zjawiskiem jest wzrost wskaźnika bieżącej płynności w 2016 roku. Przyjmuje się, że zdolność do terminowego regulowania zobowiązań zachowana jest w przypadku, gdy wartość tego wskaźnika jest wyższa od 1 (PCIM 2018). W badanym podmiocie wskaźnik wysokiej płynności dla każdego z badanych okresów był niższy od wskaźnika bieżącej płynności. W badanym podmiocie jego wartość była prawidłowa, bowiem oscylowała wokół 1 , co jest zgodne z zaleceniami w literaturze, gdzie podaje się, że wartość tego wskaźnika powinna mieścić się w przedziale 1,0-1,2 [Gabrusewicz 2014]. W 2015 roku wskaźnik ten spadł nieznacznie poniżej 1. Najwyższy poziom wskaźnika przedsiębiorstwo osiągnęło w 2016 roku, co wynikało ze spadku poziomu zapasów. 
Tabela 5. Wartość i struktura pasywów analizowanego przedsiębiorstwa w latach 2013-2016

\begin{tabular}{|c|c|c|c|c|c|c|c|c|}
\hline \multirow{3}{*}{ Wyszczególnienie } & \multicolumn{8}{|c|}{ Wielkości w roku } \\
\hline & \multicolumn{2}{|c|}{2013} & \multicolumn{2}{|c|}{2014} & \multicolumn{2}{|c|}{2015} & \multicolumn{2}{|c|}{2016} \\
\hline & [tys. zł] & $\begin{array}{c}\text { udział } \\
{[\%]}\end{array}$ & [tys. zł] & $\begin{array}{c}\text { udział } \\
{[\%]}\end{array}$ & [tys. zł] & $\begin{array}{c}\text { udział } \\
{[\%]}\end{array}$ & [tys. zł] & $\begin{array}{c}\text { udział } \\
{[\%]}\end{array}$ \\
\hline Pasywa ogółem, w tym & 19421 & 100 & 16281 & 100 & 19827 & 100 & 20021 & 100 \\
\hline Kapitał własny ogółem & 2506 & 13 & 2984 & 18 & 3443 & 17 & 3808 & 19 \\
\hline Kapitał własny spółki dominującej & 2506 & 13 & 2984 & 18 & 3443 & 17 & 3808 & 19 \\
\hline Wyemitowany kapitał & 200 & 1 & 200 & 1 & 200 & 1 & 200 & 1 \\
\hline Wynik finansowy (zysk / strata) & 121 & 1 & 478 & 3 & 459 & 2 & 364 & 2 \\
\hline $\begin{array}{l}\text { Pozostałe składowe kapitału wła- } \\
\text { snego }\end{array}$ & 2186 & 11 & 2306 & 14 & 2784 & 14 & 3243 & 16 \\
\hline Zobowiązania ogółem, w tym & 16915 & 87 & 13297 & 82 & 16384 & 83 & 16213 & 81 \\
\hline Zobowiązania długoterminowe & - & - & - & - & - & - & 4520 & 23 \\
\hline $\begin{array}{l}\text { Długoterminowe kredyty i po- } \\
\text { życzki }\end{array}$ & - & - & - & - & - & - & 4520 & 23 \\
\hline Zobowiązania krótkoterminowe & 16915 & 87 & 13297 & 82 & 16384 & 83 & 11693 & 58 \\
\hline Pożyczki krótkoterminowe & 5362 & 28 & - & - & 3525 & 18 & - & - \\
\hline $\begin{array}{l}\text { Pozostałe finansowe zobowiązania } \\
\text { krótkookresowe }\end{array}$ & 11 & - & - & - & - & - & - & - \\
\hline Zobowiązania handlowe i inne & 11330 & 58 & 13150 & 81 & 12569 & 63 & 11368 & 57 \\
\hline Zobowiązania handlowe & 11329 & 58 & 13148 & 81 & 12569 & 63 & 11316 & 57 \\
\hline $\begin{array}{l}\text { Pozostałe zobowiązania krótkoter- } \\
\text { minowe }\end{array}$ & 2 & - & 2 & - & - & - & 52 & - \\
\hline $\begin{array}{l}\text { Krótkoterminowe rozliczenia mię- } \\
\text { dzyokresowe }\end{array}$ & - & - & - & - & - & - & - & - \\
\hline $\begin{array}{l}\text { Zobowiązania z tytułu bieżącego } \\
\text { podatku dochodowego }\end{array}$ & 212 & 1 & 147 & 1 & 290 & 1 & 325 & 2 \\
\hline
\end{tabular}

Źródło: opracowanie własne na podstawie danych z bazy EMIS. https://www.emis.com/php/macro/overview/ index (dostęp 22.11.2017 r.).

Dla badanego przedsiębiorstwa wskaźnik zadłużenia ogólnego oscylował wokół 0,8. Im większa jest wartość tego wskaźnika, tym wyższe ryzyko ponosi kredytodawca. Za granicę nadmiernego ryzyka kredytowego przyjmuje się wartość wskaźnika powyżej 0,60 [Zając i in. 2016]. Największy poziom wskaźnik ten osiągnął w 2013 roku, co było spowodowane wzrostem poziomu zobowiązań handlowych oraz pożyczek krótkoterminowych. Poziom wskaźnika był w każdym badanym roku wyższy od rekomendowanego, co wskazuje na wysokie ryzyko kredytowe. Od 2010 roku wskaźnik zadłużenia kapitału własnego był powyżej 1, co oznacza, że w strukturze pasywów przeważał kapitał obcy. Przez większość badanego okresu przedsiębiorstwo nie zaciągało zobowiązań długoterminowych. Jedynie w 2016 roku zaciągnięto kredyt długoter- 
Tabela 6. Wybrane wskaźniki charakteryzujące analizowane przedsiębiorstwo w latach 2010-2016

\begin{tabular}{lccccccc}
\hline \multirow{2}{*}{ Wskaźnik } & \multicolumn{6}{c}{ Wielkości wskaźnika w roku } \\
\cline { 2 - 7 } & 2010 & 2011 & 2012 & 2013 & 2014 & 2015 & 2016 \\
\hline Wskaźniki płynności bieżącej & 1,23 & 1,19 & 1,18 & 1,12 & 1,16 & 1,16 & 1,58 \\
Wskaźnik płynności szybkiej & 1,12 & 1,06 & 1,09 & 1,01 & 1,06 & 0,98 & 1,43 \\
Wskaźnik zadłużenia ogólnego & 0,80 & 0,81 & 0,83 & 0,87 & 0,82 & 0,83 & 0,81 \\
Wskaźnik zadłużenia kapitału własnego & 3,89 & 4,39 & 4,78 & 6,75 & 4,46 & 4,76 & 4,26 \\
Wskaźnik zadłużenia długoterminowego & 0,00 & 0,08 & 0,00 & 0,00 & 0,00 & 0,00 & 1,19 \\
Wskaźnik rentowności aktywów ROA [\%] & 1,13 & 0,83 & 1,23 & 0,62 & 2,93 & 2,32 & 1,82 \\
Wskaźnik rentowności kapitałów własnych ROE [\%] & 5,53 & 4,47 & 7,08 & 4,82 & 16,01 & 13,34 & 9,56 \\
\hline
\end{tabular}

Źródło: opracowanie własne na podstawie danych z bazy EMIS, https://www.emis.com/php/macro/overview/ index (dostęp 22.11.2017 r.).

minowy, co przełożyło się na wzrost wskaźnika. Optymalny poziom wskaźnika określa się na poziomie 0,5-1,0 [Sierpińska, Jachna 2004]. Poziom 1,19 wynika z pojawienia się zobowiązania długoterminowego i nieznacznie wykracza poza przedział wskazany w literaturze jako optymalny.

Wskaźnik rentowności aktywów porównano z poziomem inflacji. Badacze często odnoszą się w analizach ekonomicznych do tego wskaźnika makroekonomicznego [m.in. Siudek, Drabarczyk 2015, Wielicka-Gańczarczyk 2015]. Na podstawie przedstawionych danych można zaobserwować, iż w latach 2010-2012 poziom wskaźnika ROA analizowanego przedsiębiorstwa był niższy od wskaźnika inflacji. Od 2013 roku wskaźnik ten utrzymywał się na poziomie wyższym niż inflacja i było to zjawisko pozytywne. Natomiast wskaźnik rentowności kapitałów (ROE) od 2014 roku stopniowo malał, co oznacza, że każda złotówka zaangażowanego kapitału własnego przynosiła coraz mniejszy zysk. Najkorzystniejszy wskaźnik spółka osiągnęła w 2014 roku (rysunek1.).

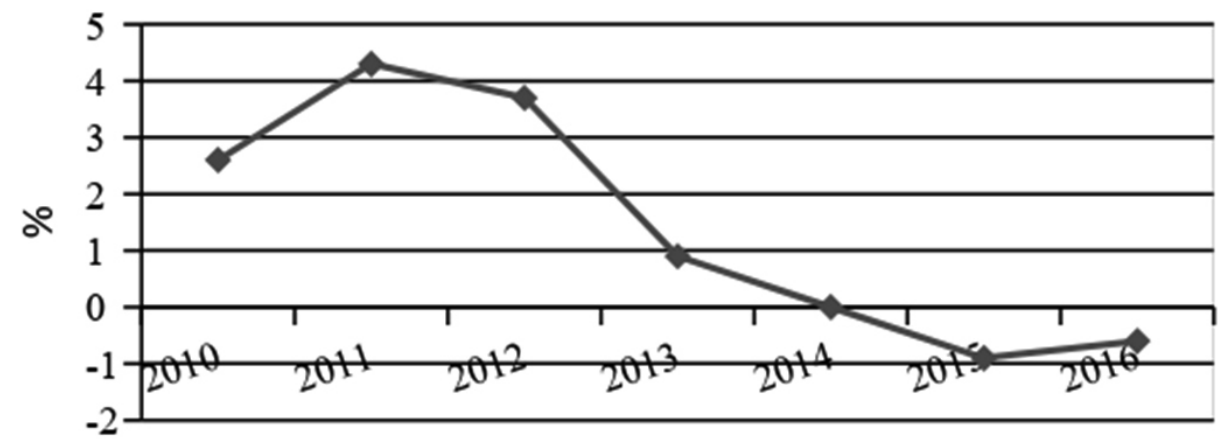

Rysunek 1. Roczne wskaźniki cen towarów i usług konsumpcyjnych w latach 2010-2016

Źródło: opracowanie własne na podstawie danych GUS, https://stat.gov.pl/obszary-tematyczne/ceny-handel/ wskazniki-cen/wskazniki-cen-towarow-i-uslug-konsumpcyjnych-pot-inflacja-/roczne-wskazniki-centowarow-i-uslug-konsumpcyjnych/(dostęp 30.04.2018r.). 


\section{PODSUMOWANIE I WNIOSKI}

Funkcjonowanie przedsiębiorstw w warunkach gospodarki rynkowej wymaga prawidłowej oceny ich sytuacji finansowej. Zarządzanie przedsiębiorstwem jest nieustannym procesem inicjowania działań. Podejmowanie decyzji dotyczących celów przedsiębiorstwa jest niemożliwe bez wiarygodnych informacji ekonomiczno-finansowych. Podstawowym źródłem informacji o przedsiębiorstwie jest sprawozdanie finansowe. Jego analiza poszerzona o analizę wskaźnikową pozwala na zobrazowanie kondycji ekonomicznej firmy.

Przeprowadzona analiza wybranego przedsiębiorstwa produkującego i sprzedającego rośliny ozdobne na podstawie danych zawartych w sprawozdaniach finansowych nie wykazała istotnie niepokojących zjawisk. Uzyskane przez firmę wartości wybranych wskaźników w większości nie odbiegały znacząco od zalecanych norm. W ostatnich trzech latach firma osiągała satysfakcjonujący poziom wskaźnika ROA, tj. wyższy niż poziom inflacji, oraz ROE, którego wartość nie spadła poniżej 9,56\%. Niepokojącym zjawiskiem może być poziom wskaźnika zadłużenia ogólnego, jaki charakteryzował spółkę w badanym okresie. Wskaźnik ten co roku przekraczał 0,80, przy czym rekomendowana wartość wskaźnika nie powinna przekraczać 0,60. Pojawienie się zobowiązania długoterminowego w 2016 roku skutkowało wzrostem wskaźnika zadłużenia długoterminowego, który osiągnął poziom 1,19 . Wskaźnik ten nieznacznie wykraczał poza wartości optymalne wskazywane w literaturze, natomiast spółki, które mają wyższy stosunek długoterminowych zobowiązań do kapitałów własnych mogą być uznawane za nadmiernie zadłużone. Natomiast badane przedsiębiorstwo nie miało problemów z regulowaniem zobowiązań bieżących. W każdym badanym roku wskaźnik płynności bieżącej osiągał prawidłową wartość, nie niższą niż 1,12. Najkorzystniejszy poziom tego wskaźnika $(1,58)$ spółka osiągnęła w 2016 roku.

Należy jednocześnie podkreślić, iż konieczne są dalsze systematyczne badania sytuacji przedsiębiorstw, aby można było dokonać pełnej oceny kondycji ekonomicznofinansowej gospodarstw kwiaciarskich w Polsce.

\section{LITERATURA}

Antczak Joanna 2014: Sprawozdawczość finansowa źródtem informacji dla controllingu. „Zeszyty Naukowe Uczelni Vistula", 35, s. 28-44.

Bednarski Lech 2007: Analiza finansowa w przedsiębiorstwie, Warszawa, PWE, s. 50-123.

Domagalska-Grędys Marta 2009: Rozwój jako element strategii gospodarstwa kwiaciarskiego, „Zeszyty Naukowe Szkoły Głównej Gospodarstwa Wiejskiego w Warszawie. Ekonomika i Organizacja Gospodarki Żywnościowej”, nr 75, s. 23-38.

Dynus Magdalena, Kołosowska Bożena, Prewysz-Kwinto Piotr 2002: Zarzqdzanie finansami przedsiębiorstw (zbiór zadań), TNOiK, Toruń, s. 123-135.

Gabrusewicz Wiktor, 2014: Analiza finansowa przedsiębiorstwa. Teoria i zastosowanie, PWE, Warszawa, s. 334.

EMIS- https://www.emis.com/php/macro/overview/index [dostęp: 22.11.2017].

Gad Jacek 2015: Analiza i ocena sytuacji finansowej przedsiębiorstwa [w] Ekonomia finanse prawo gospodarcze. Podręcznik dla sędziów i prokuratorów, Krajowa Szkoła Sądownictwa i Prokuratury, Łódź - Lublin, s. 69-77.

GUS https://stat.gov.pl/obszary-tematyczne/ceny-handel/wskazniki-cen/wskazniki-cen-towarowi-uslug-konsumpcyjnych-pot-inflacja-/roczne-wskazniki-cen-towarow-i-uslug-konsumpcyjnych/ [dostęp: 30.04.2018]. 
Jabłońska Lilianna 2007: Ekonomiczne aspekty rozwoju sektora kwiaciarskiego w Polsce, Wydawnictwo SGGW, Warszawa.

Marosz Adam 2017: Analiza wyjściowa sytuacji środowiskowej w sektorze produkcji roślin ozdobnych $w$ Polsce $w 2015$ roku, Infrastruktura i ekologia terenów wiejskich, T.I, z. 1, s. 55-70.

Olewnicki Dawid 2011: Przemiany w gospodarce ogrodniczej w Polsce $w$ latach 1965-2008 oraz perspektywy jej rozwoju, Praca doktorska, SGGW, Warszawa.

Olewnicki Dawid 2015: Zmiany w szkótkarstwie ozdobnym w ujęciu ogólnopolskim i wojewódzkim, „Europa Regionum”, T. 22, s. 171-182.

Olewnicki Dawid 2017: Rynek firm zajmujących się rozmnażaniem roślin $w$ Polsce ,Roczniki Naukowe Stowarzyszenia Ekonomistów Rolnictwa i Agrobiznesu”, T.19, z. 6, s.194-199.

Olewnicki Dawid, Jabłońska Lilianna 2018: Polski handel zagraniczny produktami kwiaciarskimi, „Zeszyty Naukowe Szkoły Głównej Gospodarstwa Wiejskiego w Warszawie. Problemy Rolnictwa Światowego", T. 18 (XXXIII), z. 1, s. 176-182.

PCIM-Polski Instytut Credit Management 2018: Pogłębiona ocena sytuacji finansowej na podstawie analizy wskaźnikowej. Podręcznik szkolenia, www.picm.pl (dostęp: 1207 2018).

Pomykalska Bożena, Wypych Mirosław 2000: Sprawozdania finansowe jako źródło informacji o przedsiębiorstwie i podstawa podejmowania decyzji $[\mathrm{w}]$ Finanse przedsiębiorstwa z elementami zarzadzania i analizy, Wypych Mirosław (red.), Wyd. ABSOLWENT, Łódź, s. 183-184.

Sierpińska Maria, Jachna Tomasz 2004: Ocena przedsiębiorstwa wedtug standardów światowych, PWN, Warszawa, s. 168.

Siudek Tomasz, Drabarczyk Katarzyna 2015: Efektywność działania wybranych banków spółdzielczych (na przykładzie województwa mazowieckiego), Zeszyty Naukowe Szkoły Głównej Gospodarstwa Wiejskiego Ekonomika i Organizacja Gospodarki Żywnościowej, nr 110, s. 53-65.

Szczecińska Beata 2014: Analiza finansowa wybranych przedsiębiorstw przemystu spożywczego, „Folia Pomeranae Universitatis Technologiae Stetinensis”, 308(74)1, s. 111-120.

Wielicka-Gańczarczyk Karolina 2015: Problematyka stosowania wskaźników ekonomicznych w ocenie kondycji finansowej podmiotów leczniczych. Zeszyty Naukowe Politechniki Śląskiej- Organizacja i Zarządzanie, Z. 78, s. 505-516.

Wróblewska Wioletta 2007: Rynek materiału wyjściowego ozdobnych roślin cebulowych w Polsce $i$ Holandii, Praca doktorska, Akademia Rolnicza, Lublin.

Zając Stanisław, Izdebski Waldemar, Skudlarski Jacek 2016: Analiza ekonomiczno-finansowa na przykładzie przedsiębiorstwa z branży produkcji maszyn rolniczych [w] Zarzadzanie w sektorach prywatnym oraz publicznym, Lenik Piotr (red.), Prace naukowo-dydaktyczne Państwowej Wyższej Szkoły Zawodowej im. Stanisława Pigonia w Krośnie, nr 70, s. 387-409.

\section{Dawid Olewnicki, Kinga Cichocka}

\section{EVALUATION OF THE ECONOMIC AND FINANCIAL CONDITION OF AN ENTERPRISE PRODUCING AND SELLING ORNAMENTAL PLANTS}

\section{Summary}

The aim of the study was to assess the financial and economic situation of the company specialized in producing and selling ornamental plants in 2010-2016. The structure of assets, liabilities and the following indicators: debt, profitability, current liquidity (CR), quick liquidity $(Q R)$ were analyzed. The analysis based on the financial statements data did not reveal any significant or alarming threats. The 
values of selected indicators mostly did not deviate from the norm considerably. In the last three years the company achieved a satisfactory level of ROA, i.e. higher than the level of inflation and ROE, which value did not fall below $10 \%$.

Adres do korespondencji:

dr Dawid Olewnicki (orcid 0000-0002-3096-3882)

Samodzielna Pracownia Organizacji i Ekonomiki Ogrodnictwa Wydział Ogrodnictwa, Biotechnologii i Architektury Krajobrazu Szkoła Główna Gospodarstwa Wiejskiego w Warszawie ul. Nowoursynowska 159 02-776 Warszawa dawid_olewnicki@sggw.pl 